\title{
The Make-or-Buy Decision in the Croatian Shipbuilding Industry: A Transaction Cost Economics Approach
}

Ermacora Sergio, Smajić Senada*

Abstract:

This paper examines the make-or-buy decision in the Croatian shipbuilding industry using a Transaction Cost Economics Approach. In other words, shipyards' decision to 'make' a component or to 'buy' it from market firms is analysed in relation to certain characteristics of the transactions in order to assess whether this decision is made in accordance with the theory's predictions.

The empirical investigation, which is based on a sample of 167 observations, suggests that transaction cost hypotheses are only partially confirmed. Namely, while physical asset specificity and complexity are likely to increase the probability that a transaction will be internalised, temporal asset specificity and frequency seem not to affect significantly the integration decision. However, as the analysis leaves much of the variance in the patterns of vertical integration unexplained, the finding presented in this study should be seen as tentative. The inclusion of the remaining shipyards in the analysis as well as of new and more variables in the model are likely to improve the reliability of the results.

JEL: D23, L14, L22, L62

DOI: $10.2478 / v 10033-009-0006-3$

\section{Introduction}

This paper considers the transaction cost explanation of the make-or-buy decision. A Transaction Cost Economics (TCE) approach is used as it allows for accounting not only for production costs but for transaction costs as well, which may be equally important in deciding whether to internalise the production of an input or to contract it out from market firms. There are a number of studies that have applied a transaction cost economics approach and their results usually confirm the predictions of the theory, i.e. the probability that a firm will internalise a transaction is higher when the production process implies relationship-specific assets as well as when complexity, uncertainty and frequency are relatively high compared to other inputs. However, the majority of these studies focuses on industries other than manufacturing and refers in particular to cases in the United States and the United Kingdom.

Towards the goal of improving our understanding of the decision to vertically integrate, this research applies the transaction cost approach to commercial shipbuilding, an industry that has been insufficiently researched in Croatia, a developing, former socialist

\footnotetext{
* Ermacora Sergio

Independent Researcher

Bosnia \& Herzegovina,

E-mail: sergio.ermacora@gmail.com

Smajić Senada

LSE Consortium Sarajevo,

Bosnia \& Herzegovina

E-mail: senada.smajic@gmail.com
} 
Eastern European country. The main objective is to assess whether, in the case of Croatian shipyards, the theory is confirmed by the empirical work; in other words, whether, after controlling for several effects, different characteristics of a transaction such as asset specificity, complexity and frequency affect significantly the choice of alternative organisational forms. Another objective is to identify if the size of the shipyard has a significant influence on the governance choice. Finally, the study aims at finding out whether diverse subsystems ${ }^{1}$ are likely to affect the integration decision differently.

The rest of the paper is structured as follows. Section two gives an overview of the literature regarding the theoretical foundations of TCE and its empirical application on the make-or-buy decision. Various concrete definitions of transaction costs are cited, which are necessary to explain the intrinsic differences with neoclassical production costs. Following this, the theoretical foundations of the TCE approach are presented with a particular emphasis on the work of its founder, Oliver Williamson. In addition, the concepts of make-or-buy and hold-up are explained in detail. The last part of the section refers to the empirical evidence of the TCE theory with a particular emphasis on its application on the make-or-buy decision.

The third section is an overview of the historical development of the Croatian shipbuilding industry, which gives a background for the empirical work presented in the fourth section. The first part of the section analyses the industry during the Yugoslav socialist period, which was unique as almost the whole production process was organised in-house. In addition, the difficulties encountered in the restructuring of Croatian shipyards in the posttransition period and the solutions to these problems are presented. Finally, an overview of the current state of the industry is given with a particular emphasis on the outsourcing decision and supply chain.

In the fourth section the empirical analysis is carried out. First, the differences between the application of the TCE approach in a typical manufacturing industry

\footnotetext{
${ }^{1}$ The ship is a system of different parts: in this study components and tasks are grouped in five subcategories (hull, machinery, outfitting, electrical and a miscellaneous category)
}

and in the shipbuilding industry are described. This is because the process of building a ship is considered to be more similar to a construction project than to manufacturing operations, and hence, this can affect the circumstances that give rise to opportunistic behaviour and to the subsequent hold-up problem. Second, the methodology used to perform the test as well as the data and the way it was collected are described. Furthermore, the variables used in the empirical model and their expected impact on the make-or-buy decision are explained. Finally, the results of the empirical estimation with different functional forms are presented and discussed. The final section gives concluding remarks; the issues raised in the previous sections are analysed in more detail and some directions for future research are given.

\section{Literature Review of Transaction Cost Economics}

"The main reason why it is profitable to establish a firm would seem to be that there is a cost of using the price mechanism"

Coase (1937: 391)

A fundamental question for the firm is to decide what it will make and what it will buy. Historically, this decision has been made taking into account only the costs of production, but firms are becoming more aware of the strategic implications of such decisions and understand the importance of considering several other factors. As explained by Williamson (1985:17) the make-or-buy decision is the paradigm problem of TCE which is solved by the "economic institutions of capitalism (who) have the main purpose and effect of economising on transaction costs". TCE analyses simply why firms exist and what their economic function is; in other words, why certain transactions are organised internally while other are mediated through markets (Milgrom and Roberts, 1992).

\subsection{What are Transaction Costs?}

Providing an answer to the question posed in the above subtitle is indeed crucial, as without a clear-cut definition the transaction cost approach will be unable to explain the differences amongst the choice of 
governance structures. It is hence important to distinguish transaction costs from the already well defined category known as production costs.

Amongst the first who tried to answer this question was Ronald Coase (1937:391) in his seminal article "The Nature of the Firm" where he notes that the most important costs "of organising production through the price mechanism are that of discovering what the relevant prices are...and the costs of negotiating and concluding separate contracts for each exchange transactions which takes place on the market". However, Hodgson (1988) argues that this definition may refer only to the costs of gathering the relevant price information rather than on the total cost of completing the transaction. Kenneth Arrow (1969) defines such costs as the costs of running the system, succeeding in this way in distinguishing them from the costs of producing goods and services that are included in the production function. Hodgson (1988) criticised this definition for being too vague.

Williamson (1985: 19) uses an analogy and explains transaction costs as "the economic equivalent of frictions in physical system". Furthermore, he argues that although several economists were aware of the problem of 'frictions', they were not able to define it. However, Hodgson (1988) debates that an analogy is not a substitute for a definition and criticised it for being misleading. Additionally, he refers to the work of Dahlman (1979) for being able to give a more precise definition of the analysed concept of transaction costs. Dahlman (1979: 148) includes three different types of costs; search and information costs, bargaining and decision costs, policing and enforcement costs, that he merges into a single one as they all "represent losses due to lack of information". Dahlman's definition makes a clear distinction between transaction costs that arise due to information imperfections and production costs that arise due to the use of factors of production. Hendrikse (2003) notes that this distinction is crucial for TCE theory as this approach simplifies these costs so that they can be determined separately and added together to obtain the costs associated with a particular governance structure. His final note is "that production costs can be ignored in determining the most efficient choice of governance" as this choice is based on minimising transaction costs (Hendrikse, 2003: 211). However, Rao (2003) argues that concentrating only on the costs of information and related organisations may sometimes be insufficient to understand total costs, and suggests the inclusion of opportunity costs of alternative governance structures as a solution.

In one of the most important classifications, Milgrom and Roberts (1992) distinguish between two types of transaction costs. The first type, known as coordination costs, includes the direct costs of collecting and transmitting information as well as the costs of delays resulting from the communication and elaboration of this information. These costs occur because decision makers face insufficient or inaccurate information and are closely associated with the make-or-buy decision. Coordination problems are resolved by organising transactions through different governance structures. The second type, known as motivation costs, is related to informational asymmetries and imperfect commitment. These costs are associated with the 'hold-up' problem, as motivational problems are likely to increase the incentive for some parties involved in the contract relationship to engage in opportunistic behaviour.

\subsection{Theoretical Background of the Transaction Cost Economics Paradigm}

The theoretical background of the transaction cost paradigm was first introduced by Coase (1937), who explained that the boundaries of the firm do not depend only on the available technology, but on the costs of transactions as well. He explained that in some instances the costs of contracting in the market may be higher than those of exchange inside the firm. The costs of these transactions may be reduced by internalising some activities into the firm. The Coasian framework helps to understand not only the existence of the firm, but also its size and scope. According to his work, the size of the firm is identified by the point where the marginal cost of transacting in the market equals the marginal cost of additional mistakes and more administration in the firm. His contribution is important because using the transaction as the basic 
unit of analysis and identifying uncertainty as a relevant factor in decision-making ${ }^{2}$, he was able to represent the firm not only as a part of the market but also as an alternative to it; in other words, a firm can decide whether to organise a transaction internally or through the market mechanism.

The questions raised by Coase (1937) on the nature of the firm were later developed by Williamson in his famous books Markets and Hierarchies (1975) and The Economic Institutions of Capitalism (1985), who created a stronger basis for the transaction cost approach. The main idea of this approach was to describe firms not in neoclassical terms, i.e. as a production function, but in organisational terms, i.e. as governance structures (Boerner and Macher, 2002). Williamson's framework is based on the interaction between two behavioural assumptions (bounded rationality and opportunistic behaviour) and three dimensions of transactions (asset specificity, uncertainty and frequency).

Bounded rationality is explained by Simon (1961: xxiv) as human behaviour that is "intendedly rational, but only limitedly so". In other words, decision-makers are constrained by neurophysiological limits that are reflected in the lack of cognitive capabilities of processing and storing information, and by language limits, which refer to the inability to express thoughts and feelings in a way that is fully comprehensive to others (Rindfleisch and Heide, 1997). Parties involved in a contract cannot take into consideration every possible contingency, which precludes the writing of complete contracts. However, as explained by Williamson (1975) bounded rationality becomes important only once the cognitive limits are reached. On the other hand, opportunism, defined by Williamson (1975: 26) as "self interest seeking with guile" involves "false or empty, that is, self-disbelieved, threats and promises" in the expectation of obtaining an advantage (Goffman, 1969: 105). Arrow (1969) explains that a transaction is subject to hazards of opportunistic behaviour when information is unequally distributed between the parties involved in this transaction. Yet Williamson (1976) argues that it is not asymmetric information per se that gives rise to

\footnotetext{
${ }^{2}$ According to Knight (1921) the economic system is either complex or dynamic, which creates limitations known as uncertainty
}

opportunistic behaviour, but it must be accompanied with high costs of achieving information parity, as well as with a small number condition. The latter condition is necessary as among large number of bidders opportunistic inclinations won't be successful (Williamson, 1976). However, as explained by Douma and Schreuder (1998), not everyone behaves opportunistically, although it is difficult to distinguish ex ante parties who will behave opportunistically from those who won't. To safeguard against such behaviour, TCE matches transactions that differ in their attributes, with the appropriate governance structures "in a discriminating way" (Williamson, 1985: 18). There are three critical dimensions of transactions:

a) Asset specificity refers to the degree to which a transaction needs to be supported by a relationspecific investment that cannot be redeployed without additional costs. ${ }^{3}$

b) Uncertainty about future events and other parties' actions, which is closely linked to bounded rationality

c) Frequency with which the transaction occurs that may be one-off or recurrent

Although each of these dimensions is important, the first, asset specificity, is considered crucial when deciding upon the preferred governance structure.

\subsubsection{The 'make-or-buy' Decision}

A fundamental decision that a firm has to face is the determination of when it will buy from the spot market and when it will make its own inputs. New information technologies as well as faster and more efficient ways of communicating have increased the interest in this question.

\footnotetext{
3 Williamson (1991) distinguishes amongst six types of asset specificity. First, site specificity, refers to assets that are closely located to reduce transportation and inventory costs. Second, physical asset specificity, refers to relationship specific machinery and equipment. Human asset specificity is the third type, which refers to transaction-specific know-how and skills whose value is lower outside a specific relationship than inside it. Fourth is brand name capital which is an intangible asset reflected in consumer perceptions. The fifth, dedicated assets are investments in plant and equipment made to satisfy a specific customer. The last, temporal specificity, refers to the importance of scheduling and using assets at a particular point of time
} 
The make-or-buy decision can be easily explained: economic decision-makers will choose the governance structure that minimises transaction costs. In other words, firms will organise production internally if this is the most efficient solution; otherwise, the firm will buy the necessary components from the spot market. However, while the classical literature on vertical integration focuses on the simple dichotomy between the decisions to 'make' or 'buy', TCE augments the possible arrangements with a wide range of marketbased governance structures that represent valid alternatives to both spot market transactions and vertical integration (Joskow, 2003). This is to say, governance structures include markets, hierarchies and hybrids. As explained by Shelanski and Klein (1995) the anonymous spot market is used in the case of simple transactions where basic commodities are traded, as the price mechanism allows the participants to adapt quickly to changing circumstances. On the other hand, when specialised assets are at stake and when product or input markets are thin ${ }^{4}$, integration may be desirable. TCE posits that such hierarchies represent the safeguard against opportunistic behaviour "as they provide efficient mechanisms for responding to change where coordination adaptation is needed" (Klein, 2004: 4). However, compared with a more decentralised governance structure, hierarchies tend to increase administrative and bureaucratic costs, and are likely to remove incentives to maximise profits (Bigelow, 2004). However, these two governance arrangements ${ }^{5}$ are just two polar cases. Between these two poles there is a variety of hybrid modes that include various types of franchises, joint ventures, long-term contracts, holding companies and public enterprises. It should be noted that there is a trade-off between better coordination and protection for specific investments that can be achieved in the firm on one side, and higher incentives of market relations on the other side (Shelanski and Klein, 1995). However, different organisational forms are never assessed alone; their efficiency is examined in relation to other

\footnotetext{
${ }^{4} \mathrm{~A}$ market is said to be thin when there is only a small number of buyers and sellers

5 'buy' in the case of spot markets and 'make' in the case of vertical integration
}

modes of governance. Next, the hold-up problem is analysed in more detail.

\subsubsection{The 'Hold-up' Problem}

When contracts are incomplete and the relationship involves transaction specific investments, one party may act opportunistically by attempting to renegotiate the terms of the contract, ex-post. In such cases, it may happen that a desirable investment from a welfare perspective will not be realised because of the fear of post-contractual opportunism; this situation is known as the 'hold-up' problem (Besanko et al, 1996). The hold-up problem arises because appropriable quasirents are created. As explained by Klein, Crawford and Alchian (1978), while the rent is simply the profit that a firm expects to get in the case when a specific asset is used, assuming that all goes as planned, the quasi rent is the extra profit that the firm gets if everything goes as planned, versus the profit the firm would receive if it had to turn to the second-best alternative. When a specific investment is made and such quasi-rents are created the possibility of ex-post opportunistic behaviour becomes real. The hold-up problem is crucial for the make-or-buy decision as it influences the chosen governance structure.

When the degree of asset specificity is low and there are no quasi-rents, the cost of purchasing the component from the market ('buy' strategy) is the lowest. On the other hand, when the degree of asset specificity is high and quasi-rents are at stake, vertical integration (the "make" strategy) is chosen, as ownership of transaction-specific assets is a way of safeguarding against opportunistic behaviour. Finally, when the degree of asset specificity is at an intermediate level (Hendrikse; 2003), or a relationship does involve only physical asset specificity (Monteverde and Teece, 1982a; Masten et al, 1989), a hybrid governance structure may be chosen to minimise transaction costs. It should be noted, however, that hybrid organisational structures and

\footnotetext{
${ }^{6}$ The possibility of hold-up influences the choice of organisational arrangements, i.e make-or-buy; the higher the probability of ex-post opportunistic behaviour the more likely is the transaction to be internalised.
} 


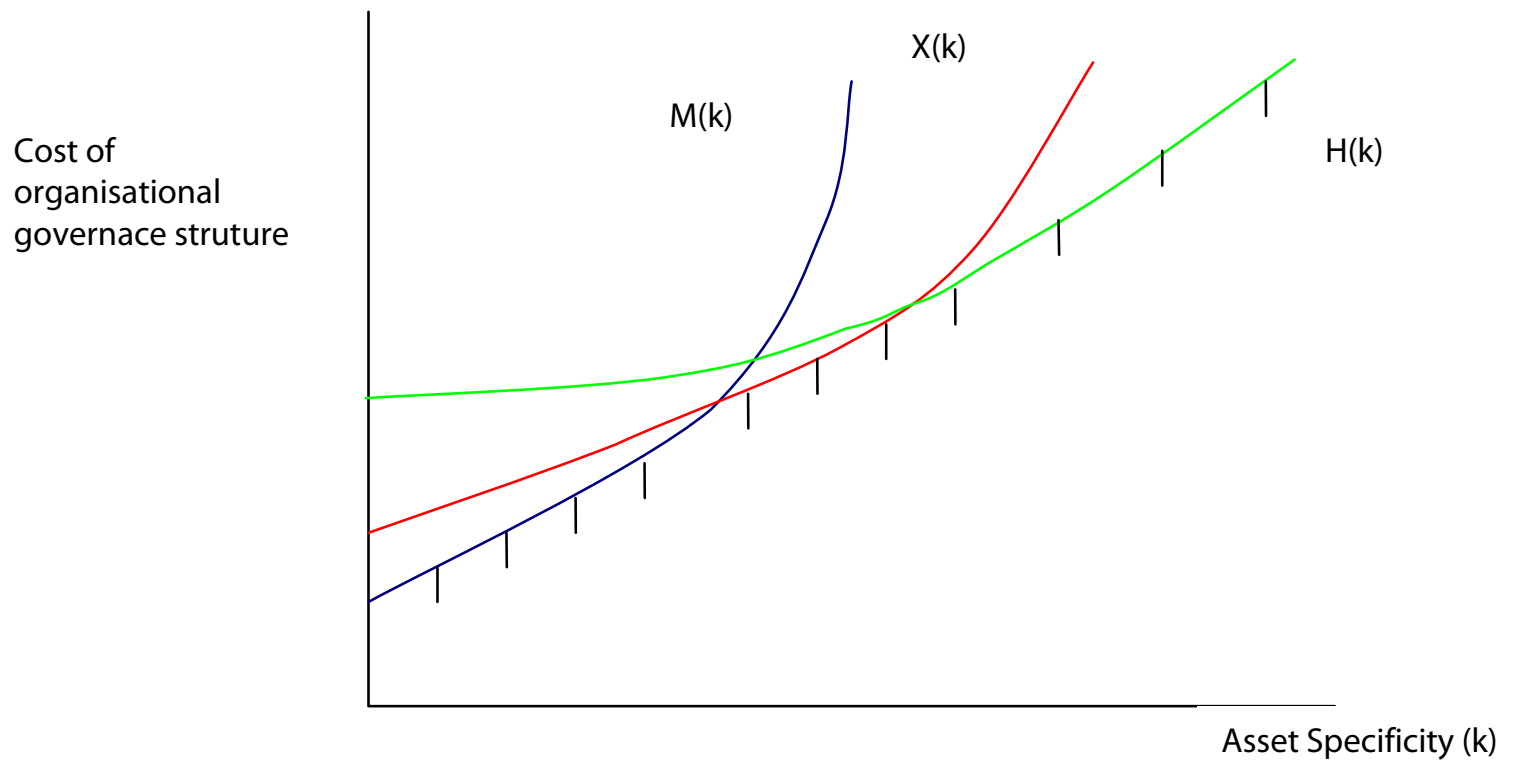

Figure 1: Efficient governance structure choice in relation to asset specificity

Source: Hendrikse (2003: 215)

vertical integration can only mitigate opportunistic behaviour.

To conclude, it is important to stress that both the make-or-buy decision and the hold-up problem are important factors to consider when analysing the Croatian shipbuilding industry because of the important role played by outsourcing and contract design in this industry.

\subsection{Empirical Evidence on Transaction Cost Economics}

The emergence of TCE during the 1970's and 1980's has created a substantial body of empirical work, and the number of studies has been estimated in a recent survey by Boerner and Macher (2002) to be over 600 . Transaction cost reasoning has been applied in several business-related fields, as well as in other disciplines that are not so closely related to business (Boerner and Macher, 2002; Klein, 2004).

The empirical literature on TCE employs a variety of econometric and historical methods. According to these methods, most authors (Klein and Shelanski, 1995; Boerner and Macher, 2002; Klein, 2004) have divided the empirical literature into three broad categories:

1. Qualitative case studies
2. Quantitative studies

3. Cross-sectional econometric analysis

The first category refers to researches based on a particular event or transaction. The TCE literature contains a large number of good case studies, of which one example is Williamson's (1976) analysis of cable television franchising ${ }^{7}$. Case studies are the most frequent form of empirical analysis in TCE due to following reasons. First, the main variables in the TCE analysis are very difficult to measure quantitatively and are usually collected using questionnaires and surveys. As a result, the data are based on the respondents' stated beliefs and subjective valuations. Secondly, as these measures are based on ordinal ranking, it is hard to compare data obtained from different industries. However, although case studies are not affected by these problems, they have been criticised for being too specific.

The second category includes quantitative studies that examine some specific aspects of governance structure or contract. Good examples of this category are Masten's (1984) investigation of the contracting practices in the US aerospace industry and Walker and

\footnotetext{
${ }^{7}$ Other examples of case studies refer to organisational arrangements between rail operators and freight (Palay, 1984), between coal mines and electric utilities (Joskow, 1985) and the acquisition of Fisher Body by GM (Coase, 2000; Klein, 1988; Klein, 2000).
} 
Weber's (1984) study of automobile component procurement. These studies usually use a probit or logit model, where the dichotomous dependent variable is the chosen governance structure ('make' or 'buy') while the independent variables, measured by proxies such as asset specificity, uncertainty and frequency are the key attributes of the transaction. In general, the results of these models are consistent with the predictions of the theory.

The third category attempts to measure transaction costs directly and consistently across different firms and industries. Levy's (1985), MacDonald's (1985) and Caves and Bradburd's (1988) examinations of vertical integration are only some of the examples included in this category ${ }^{8}$.

The first part of this section has tried to categorise the empirical literature in TCE. Next, the analysis will assess the empirical work on component procurement and, in particular, the one related to shipbuilding, as a background for the empirical investigation that will be undertaken in section three.

The contribution of Masten (1984) on the make-orbuy decision, as well as that of Masten et al. (1991) and Love and Stephen (1999), in the particular case of the shipbuilding industry, have been very significant, and represent the basis of this paper. Masten (1984) analyses the procurement decision in the US aerospace industry using a sample of 1,887 components that are either coded as made or bought, and focuses on the effect of asset specificity and uncertainty as determinants of vertical integration. Questionnaires were designed to collect information about the different variables included in the model that were completed by a team of company representatives. Using a probit model since the variable is dichotomous (either 'make' or 'buy') Masten concludes that the probability that a transaction will be internalised is higher the more complex and specific the design of a component.

\footnotetext{
${ }^{8}$ Beside these three main categories, transaction cost economists are trying to implement new methods with the aim of overcoming the shortcomings of the techniques currently used. One modern approach that is gaining increasing importance is the two stage approach first implemented by Masten et al (1991) as well as panel data estimation, good examples of which are the estimation of Gonzalez-Diaz et al (2000) of subcontracting decisions in the Spanish construction industry and Bigelow's (2004) analysis of the US automobile industry.
}

Additionally, Masten et al (1991) analyse the procurement decision in a large US naval shipbuilder. While other studies assess the make-or-buy decision in the manufacturing industry, their study attempts to test the TCE hypothesis in the construction industry. Using a probit estimation as well as a two stage approach, Masten et al (1991) investigate the relationship between in-house production and asset specificity, along with complexity and other control variables. The results indicate that temporal specificity has the most significant influence on the integration decision followed by human asset specificity. However, the estimated coefficient on physical asset specificity is significantly negative, which can be explained by the recent theoretical and empirical developments suggesting that problems related to relationshipspecific physical capital can be dealt using quasivertical integration ${ }^{9}$. In addition, they found evidence that the firm is more likely to integrate activities that are more similar to their core business, such as labour intensive operations and those that are candidates for "load levelling".

Finally, Love and Stephen (1999), in a study of UK naval shipbuilding augmented Masten et al's (1991) model with a variable that controls for economies of scale and with another variable that captures the effect of frequency on the cost of hold-up. They found that the number of suppliers, as well as the degree of human asset specificity, is not likely to affect the cost of hold-up, while the other TCE variables such as frequency, physical and temporal specificity are in accordance with the theory's predictions.

The importance of these studies in terms of this paper is multiple. First, the study of Masten (1984) is significant because of the use of a qualitative dependent variable model such as probit, in which the values of this dependent variable are bounded by 0 and 1, which will also be applied in the empirical section of this paper. Second, the work of Masten et al (1991) indicates that shipbuilding is an industry suitable to be analysed through a TCE lens, while the applied methodology shows that transaction costs can be analysed using complex econometric techniques.

\footnotetext{
${ }^{9}$ In other words, these specialised assets are owned by the prime contractor
} 
Third, the research of Love and Stephen (1999) is notable for the inclusion of several control variables and because it indicates that more than one precedent study exists in the area to follow. Finally, all these studies used questionnaires to collect the data used in their empirical investigations.

\section{The Croatian Shipbuilding Industry}

\subsection{Historical Overview}

Shipbuilding and ship-repairing activities in Croatia have a long tradition. Thousands of vessels of all types were built by local inhabitants from time immemorial until today. Most of the shipyards on the Eastern Adriatic coast were founded as Austrian Naval Arsenals in the nineteenth and beginning of the twentieth century. They were amongst the most successful shipyards from that time, and specialised in the construction of naval ships, ranging from battleships to cruisers and submarines (www.hb.hr). Some decline in the shipbuilding activity was registered during the first Yugoslav (1918-1941) and Italian administration, as the administrative centres were far from the coast and not interested in developing the littoral economy (Bartlett et al, 2002). After World War II, the eastern Adriatic coast became part of the Federal Republic of Yugoslavia, and so was the case with its shipyards. However, almost $80 \%$ of the shipbuilding capacity was severely damaged or in need of replacement (Bateman et al, 1998). The Yugoslav state, which was the new owner of the shipyards, started the reconstruction of the existing complexes and the building of a new shipyard soon after the end of the world's largest conflict. However, in socialist countries profitability was not a determinant of the efficacy of a firm, and hence it was not shipyards' main concern as before and still is the case in modern capitalistic economies. Shipyards were organised in accordance with socialism's principles of production: they were multifunctional units in which shipbuilding was just one objective, while other objectives were the provision of social services to employees and the maintenance and enforcement of some political power and control (Bitzer and von Hirschhausen, 1997). To achieve these aims socialist countries tended to organise the complete production process in-house. However, when almost all transactions are internalised, transaction costs are likely to rise substantially. As explained by Coase (1937) and Williamson $(1975 ; 1985)$ the costs of transacting may be reduced by combining different governance structures, or, in other words, by organising some activities inside the firm while contracting out others from the market.

As was the case with other socialist countries, Yugoslav shipyards were characterised by a high degree of self-sufficiency; deep vertical integration with the in-house capacity to manufacture almost everything that went into a modern ship apart from some sophisticated components. The three largest shipyards, Uljanik, 3Maj and Brodosplit were already almost completely vertically integrated and selfsufficient in the 1950s: they produced diesel engines, ship outfits, cranes, generators, machinery equipment including winches, accommodation, sanitary equipment, switchboards, etc. In some cases these shipyards produced even the actual capital equipment used in the production process ${ }^{10}$ (Bateman et al, 1998). On the other hand, the two medium-sized shipyards Kraljevica and Trogir - were involved in some shiprepairing work and in the construction of smaller and less complex ships. These shipyards were less vertically integrated than the three largest ones, and bought-out the majority of parts, components and subcomponents from the latter. This tendency can be explained by the lower degree of asset-specificity necessary to build less complex ships, and by the insufficient amount of competent and specialised human capital in these territories.

It is important to stress the escalation of the Yugoslav shipbuilding industry, which in the 1960s and 1970s was ranked as the world's third largest by tonnage output after Japan and South Korea. However, despite the high level of productivity and lower wages compared with Japan and Western European Countries, Yugoslav shipyards encountered several difficulties to break even. The number of orders

\footnotetext{
${ }^{10}$ For example, Uljanik started the production of welding machines soon after the introduction of welding techniques in the hull construction, while $3 \mathrm{Maj}$ produced cranes used in the construction phase.
} 
reduced during the 1980s and crashed after Yugoslavia incurred the biggest financial crisis in its history and finally disaggregated (Bartlett et al, 2002).

\subsection{The Post-Socialist Period}

After becoming independent in 1991, Croatia inherited the major part of the former Yugoslav shipbuilding capacities. However, the industry was highly indebted, partly because of some unprofitable contracts concluded at the end of the 1980s and partly due to the unsuccessful 'shock therapy'11 programme in 1989 (Bateman et al, 1998). On the other hand, the transition from planned to market economy implied profitability as an important factor when considering the efficiency of a company: once the planned economy had been left behind, the choice between different ways of transacting (governance structures) made in accordance to the related transaction costs became an important factor influencing profitability. It became clear that large and highly vertically integrated firms, with almost 10,000 employees and $90 \%$ of production made in-house would be stagnant and inefficient due to high transaction costs ${ }^{12}$. For this reason, the restructuring of the industry was necessary with particular emphasis on reducing the number of employees and increasing the level of outsourcing in key areas.

However, the necessary restructuring of the industry was put on hold during the war (1992-1995) and as a result, the Croatian shipbuilding industry fell in world rankings from the third position in 1990 to the thirteenth position in 1996 (Ministry of Economic Affairs, 1997). In 1995, the Croatian Government introduced the "Rehabilitation Act of Special Enterprises" that included state-owned shipyards: the act involved three steps. The first, rehabilitation, was designed to reduce the inherited debt of the previous

\footnotetext{
${ }^{11}$ According to this strategy the Yugoslav government made large investments in order to restructure large shipyards in a short period of time. However, even after these huge investments shipyards were still not competitive in the world shipbuilding market.

${ }^{12}$ This because the socialist way of organising production created a significant administrational and bureaucratic burden that increased prohibitively the costs of transacting (and organising production) within shipyards
}

state. To achieve this aim a debt for equity swap was arranged and, as a result, several state agencies became owners of parts of the industry (Croatia Outlook, 1997). The second phase, restructuring, has been carried out by a German consulting team that concentrated its efforts on the industry's problems and their possible solutions (Bateman et al, 1998). According to these recommendations, large shipbuilding firms were split in different parts in order to focus on their core activities. First of all, shipbuilding concerns got rid of unnecessary departments by privatising, selling or simply closing them. On the other hand, departments producing marine equipment, such as those that produced diesel engines, machinery, electrical parts and capital equipment, as well as the shipyards itself were organised as independent companies inside shipbuilding groups ${ }^{13}$. The rationale behind this decision can be explained as follows: internal organisation costs tend to be higher when transactions are intrinsically different, either by their location or some other characteristics, from other operations in which the firm is engaged (Masten et al, 1991: 14) ${ }^{14}$. Furthermore, another important part of the plan was to increase outsourcing in key areas and to develop a network of reliable small and medium suppliers and subcontractors, as several components and tasks were highly location and temporal specific. In addition, in order to gain and maintain competitiveness in the global ship market, the shipyards were supposed to specialise in certain areas of shipbuilding. Finally, shipyards introduced new types of erection technologies based on principles such as structural building in blocks, block outfitting to a maximum degree and several others (Kanerva et al, 2002).

Although progress has been significant, problems still remain as the government's attempts to privatise the remaining shipyards were not successful. In addition,

\footnotetext{
${ }^{13}$ For example, the shipyard in Split organised the construction of new ships in two companies: Brodosplit specialised in the production of large commercial ships and Brodosplit-BSO focused on the construction of smaller specialised ships, offshore objects and naval vessels.

${ }^{14}$ In other words, the bigger the differences between the shipyard's primary operations and other activities, the higher the transaction costs of organising these activities in-house.
} 
many shipyards ${ }^{15}$ tend to suffer from labour supply difficulties and are forced to hire workers from other countries such as Bosnia and Herzegovina, the Slovak Republic and the Philippines.

\subsection{The Present State of the Industry}

The shipbuilding industry is a branch that operates on the global market and in the case of Croatia is almost completely orientated on export. According to the scope of business, capacity and size of ships built, Croatian shipyards can be classified by three main categories (Croatian Chamber of Economy, 2003):

- Large shipyards - Brodosplit, 3Maj, Uljanik, Trogir, Kraljevica and Brodosplit-BSO.

- Medium-sized shipyards - less than 10.

- Small shipyards - several dozens specialised in the construction and repairing of small ships, usually on the coast, though some yards were recently built inland as well.

As this study focuses on large shipyards, it is necessary to calculate a concentration index to confirm the importance of these. However, there is no data available for sales of new ships referring to the Croatian shipbuilding industry as a whole ${ }^{16}$. However, as the smallest among the large shipyards accounts for approximately $2 \%$ of the total turnover of these six shipyards, and that there are less than 10 medium shipyards, we believe that the market share of large shipyards should not be less than $80 \%$.

\footnotetext{
${ }^{15}$ Especially those located close to the Italian border due to higher wages offered by the local shipyard Fincantieri

${ }^{16}$ We tried to collect this figure by enquiring with the Croatian Chamber of Commerce, the Croatian Statistical Bureau and the Croatian Ministry of Finance, without success.
}

\begin{tabular}{|clc|}
\hline No & \multicolumn{1}{c}{ Company } & \multicolumn{1}{c}{$\begin{array}{c}\text { Total } \\
\text { Turnover (in } \\
1000 \text { HRK) }\end{array}$} \\
\hline 1. & $\begin{array}{l}\text { BRODOSPLIT } \\
\text { BRODOGRADILIŠTE }\end{array}$ & 1.763 .714 \\
\hline 2. & ULJANIK BRODOGRADILIŠTE & 1.389 .882 \\
\hline 3. & 3. MAJ BRODOGRADILIŠTE & 1.127 .918 \\
\hline 4. & BRODOTROGIR & 568.181 \\
\hline 5. & $\begin{array}{l}\text { BRODOGRADILISTE } \\
\text { KRALJEVICA }\end{array}$ & 128.910 \\
\hline 6. & BRODOSPLIT-BSO & 119.000 \\
\hline
\end{tabular}

Market share Brodosplit-BSO =

$\frac{\text { Turnover (Brodosplit-BSO) }}{\text { Total turnover (large shipyards) }}=\frac{119000}{5097605}=0.0233=2.33 \%$

Table 1: Market share calculations

Source: Croatian Chamber of Economy, 2005. "

Shipbuilding Industry" Zagreb

The large shipyard group employs 12,400 employees in total, and are supported by a net of almost 1,500 companies (marine equipment producers, subcontractors, salespersons, etc), in particular SME's located close to shipyards. According to the 2005 world order book the Croatian shipbuilding industry was in fourth place with 69 contracted ships, behind Japan, South Korea and China (Croatian Chamber of Economy, 2005).

\begin{tabular}{|clcc}
\hline 1. & Japan & 1063 & $80.707 .413,00$ \\
\hline 2. & Korea (South) & 1038 & $75.505 .799,00$ \\
\hline 3. & China & 706 & $34.996 .822,00$ \\
\hline 4. & Croatia & $\mathbf{6 9}$ & $\mathbf{3 . 4 8 2 . 8 6 9 , 0 0}$ \\
\hline 5. & Taiwan & 45 & $2.735 .495,00$ \\
\hline 6. & Poland & 78 & $2.704 .811,00$ \\
\hline 7. & Germany & 101 & $2.637 .842,00$ \\
\hline 8. & Denmark & 16 & $1.736 .400,00$ \\
\hline 9. & Philippines & 25 & $1.324 .883,00$ \\
\hline 10. & Iran & 28 & $1.223 .800,00$ \\
\hline
\end{tabular}

Table 2: NEW BUILDINGS WORLD ORDER BOOK (3. 3. 2005.)

Source: Croatian Chamber of Economy, 2005

It is important to note that Croatian yards are prevalently focused on commercial shipbuilding, especially cargo vessels. As opposed to EU shipyards, which focus on the construction of ships for special purposes and high-tech ships, or Far East yards, specialised in the construction of low-tech ships, 
Croatian shipyards have found their place in the world's shipbuilding market by constructing specialised medium-complex merchant ships and offshore platforms ${ }^{17}$. On the other hand, while during the socialist period several warships were built, only a few small naval vessels and submarines were constructed after Croatia gained independence.

\subsubsection{Outsourcing and Supplier Chain}

As in other parts of the world, outsourcing in the Croatian shipbuilding industry began with two important areas: special equipment and workforce. However, Croatian shipyards have tried to be selective when considering the outsourcing decision, warned by bad experiences in European shipyards where outsourcing brought several new problems as technical coordination between different parties involved was difficult to manage, especially because of scheduling and complex installation.

According to its components the ship can be divided in 4 main subsystems, and the supply chain can be explained through the different processes involved in them ${ }^{18}$ :

1. Hull erection - this is one of the most important processes in a shipyard's business, and in the Croatian case it is performed prevalently by shipyards themselves. They just procure the raw material necessary for the hull, such as steel plates, panels, welding material, paints and other chemical products and perform the necessary tasks and operations such as plate cutting and forming, welding, coating and painting. Only a few components are outsourced and subcontractors are used in periods of higher demand and for jobs with uneven workload.

2. Engine, machinery and related installation several shipyards in Croatia used to manufacture their own engines and machinery. The large shipyard groups produce engines under licence of the world's biggest marine engine manufacturers,

${ }^{17}$ For example, the shipyard at Kraljevica is one of only two yards in the world actually building asphalt tankers, while the shipyard at Uljanik has a share of $8.1 \%$ in the world order book for car carriers.

${ }_{18}$ Data have been collected through questionnaires and structured interviews with managers/engineers in the relevant companies as well as other equipment such as cranes ( $3 \mathrm{Maj}$, Brodosplit), generators, battery chargers (Uljanik) and several other components. However, it is necessary to note that the satellite firms producing engines and machinery are just divisions inherited from the socialist period, and that these represent more a burden than a necessity for modern shipyards. On the other hand, shipyards tend to buy machinery from Croatian suppliers when possible ${ }^{19}$, and usually perform the related installation in-house.

3. Outfitting - Apart form some components, Croatian shipyards do not produce marine equipment, but are supported by an efficient network of domestic and foreign suppliers and subcontractors. On the other hand, the equipment is usually completely installed by the shipyard's workforce.

4. Electrics and electronics - No shipyard in Croatia produces electrical and electronic parts. They are all outsourced, partly from local suppliers (less complex parts) and partly from international suppliers (more complex parts such as radar and navigation systems). In addition, the installation of these parts is often performed in-house, while some parts are installed by the manufacturer of the component itself.

It is interesting to note that some important tasks such as design and engineering have not been outsourced because of high human specificity related to the characteristics of the ship produced and of the yard itself. When they are subcontracted, this is done on a per-discipline basis only ${ }^{20}$ (Kanerva et al, 2002). However, the problem with some Croatian shipyards is that the outsourcing decision is still too influenced by the direct purchase costs, and it does not take in consideration the possible transaction costs. The more components are delivered by suppliers the more complex coordination becomes (Bitzer and von Hirschhausen, 1997). In other words, as the level of

\footnotetext{
${ }^{19}$ Due to several pressures form various ministries pushing to increase the quantity of Croatian materials and inputs installed in a ship. Shipyards are obliged to incorporate domestic inputs even when their price is $15-20 \%$ higher then their foreign counterparts. ${ }^{20}$ i.e. steel, piping, machinery, outfitting, electricity, etc
} 


\begin{tabular}{|c|c|c|c|c|c|c|}
\hline & \multicolumn{6}{|c|}{ Company } \\
\hline & Brodosplit & 3Maj & Uljanik & Trogir & Kraljevica & Brodosplit-BSO \\
\hline Only shipyard & $50-60 \%$ & $50-60 \%$ & $50-55 \%$ & $55-65 \%$ & $55-65 \%$ & $60-65 \%$ \\
\hline Shipyard group & $35-45 \%$ & $30-40 \%$ & $35-45 \%$ & I & I & I \\
\hline Employees & 4.361 & 2.321 & 1.998 & 1.307 & 557 & 200 \\
\hline
\end{tabular}

Table 3: The level of outsourcing in major Croatian shipyards and number of employees

Source: Structured interviews with shipyards' and Croatian Shipbuilding Corporation's representatives

outsourcing increases, the coordination costs, which are just a type of transaction costs, increase as well.

If we take a further look at the level of outsourcing, it ranges between $35 \%$ and $65 \%$ depending on the shipyard, type of ship and several other characteristics.

As can be noted from table 3, the three biggest shipyards, according to the number of employees, tend to rely less on outsourcing than the three smaller ones. These differences are even more evident when considering the whole shipyard groups ${ }^{21}$. On the other hand, smaller shipyards tend to rely more on procurement; these have concentrated on steel and piping work while subcontracting outfitting and similar tasks.

It would have been interesting to study the link between the performance of individual shipyards and their level of outsourcing. However, the present state of the industry makes a similar analysis worthless; shipyards are still under restructuring and are not profitable. Furthermore, the recent unfavourable changes in the US dollar exchange rate and in the price of steel in the world market, as well as political interests in different counties where the shipyards are located, make it impossible to link the performance of these shipyards directly with their organisational arrangements. Nevertheless, it is useful to note that many shipyards in Western European countries have increased their level of outsourcing to almost 70\%, which has allowed them to drastically decrease the number of workers and to concentrate on their core business (Bitzer and von Hirschhausen, 1997). These shipyards usually perform better than those relying more on in-house production as they are able to reduce costs and attenuate the traditional problem in shipbuilding- uncertainty of demand.

\footnotetext{
${ }^{21}$ That include plants producing diesel engines and other marine equipment
}

The world shipbuilding industry has experienced significant changes during the last 20 years. From a heavy industry it has turned to a high-tech, logistically intensive production process (Bitzer and von Hirschhausen, 1997). Nevertheless, it still remains primarily a construction industry. Modern shipyards in developed countries increasingly rely on suppliers for manufacturing and even more for developing components and parts. Some shipyards have already moved towards an assembly type of production facility, in which they concentrate only on their core business, which is steel processing, hull production, piping and machinery installation as well as coordination and management of the complete project (Kanerva et al, 2002). This enables them to economise on transaction costs by focusing on primary activities while outsourcing other operations that differ substantially from these. Croatian yards are following the steps of these shipyards by restructuring their organisations from highly-integrated to nonintegrated production structures. However, a developed network of efficient and loyal suppliers and subcontractors is the necessary condition for the success of these yards. Finally, the yards have to weigh the total costs associated with the "make" and "buy" strategy, and only then decide on their preferred governance structure.

\section{Data, Methodology and Results of The Empirical Investigation}

\subsection{Specific Characteristics of the Construction Project}

Amongst the several differences between the construction project and manufacturing activity, the 
most important are the immobile nature, uniqueness and high variety of the final product (Gonzalez et al, 2000; Masten et al, 1991). While manufacturing operations imply the production of several smaller parts and products in different locations, the construction project consists of building a single or a small number of immobile structures in a particular location. On one hand, the manufacturing industry is characterised by mass production in which the use of specific assets is usually economical. On the other hand, the output of the construction project must be adaptable to particular buyers and uses. Because of the uniqueness of the final product and the unique location where the construction takes place, the assets used in the construction project are less likely to be transaction specific, i.e. they tend to be mobile and adaptable to several different uses (Gonzalez et al, 2000). Hence, physical asset specificity is considered to be a less important determinant of the governance structure in the construction industry than in manufacturing.

Another important characteristic of construction activities is the wide variety of final products that involve the mixture of dissimilar intermediate activities (Gonzalez et al, 2000). Furthermore, the production process in the construction industry usually implies the integration of relatively low technology and labour intensive activities (Hagedoorn, 1993; Eccles, 1981; Masten et al, 1991). In addition, Gonzalez et al (2000) note that in the construction industry each contract represents an important part of a firm's overall sales, i.e. the demand is of a discrete nature.

It is necessary to stress that the unique nature and location of the construction project prevents the possibility of holding buffer inventories, such as those used in the manufacturing industry. Eccles (1981) argues that in a similar environment the importance of timing and coordination becomes crucial. As many different tasks and specialities are involved simultaneously, it may happen that a new phase cannot begin until one or more others have been accomplished. This means that these phases must be scheduled strictly for the operations to proceed in a particular order. In other words, when delays happen these may prevent other activities from being completed until the precedent phase is accomplished or a new schedule is made. This may seriously affect the construction project by increasing its costs. A similar situation increases the potential for ex-post opportunistic behaviour. Even though the physical assets and human capital used to complete a phase of work may not be relationship specific, it is often extremely difficult to find another supplier that could perform the task or produce the component to suitable quality. On the other hand, as explained by Masten et al (1991) the contracting solution can just imperfectly solve similar hold-up problems, depending on the nature of the transaction. However, some specifications and completion dates may vary during the course of the project, changing in this way the original plan as well as its costs. Hence, as it is impossible to account for all possible contingences even in the most simple setting without incurring additional costs, contracting does not represent an acceptable solution in the construction as well as in other industries when transactions are complex and highly uncertain.

In sum, the distinctive characteristics between construction and manufacturing operations are likely to influence the choice of organisational form to a certain degree. In other words, the construction industry is usually associated with a higher degree of temporal specificity, which means that the chosen mode of organising a transaction will be prevalently determined by the degree to which some operations require precise scheduling. On the other hand, transaction specific physical assets and human capital tend to influence the choice of governance structure less than in manufacturing activities. However, they may influence the organisational choice of some construction activities when components that are standardised or used in a large number are produced (Masten et al, 1991).

\subsection{Data and Methodology}

To test whether the analysed shipyards tend to choose their organisational structure in accordance to that predicted by the theory of transaction costs, a probit or logit model can be used since the dependent 
variable is dichotomous: the two models give qualitatively similar results with the main difference represented by the slightly fatter tails of the logistic distribution (Gujarati, 2003: 614). Each sample component or task is coded as being prevalently produced/performed in house or by an external supplier/subcontractor ${ }^{22}$. Following Masten's (1984) model and augmenting it according to Williamson (1985) the objective is to test the following model ${ }^{23}$ :

Make strategy

$G_{i}=G_{i}^{*} \quad$ if $L_{i}^{*}\left(\omega_{i}\right)<\widetilde{L}_{i}\left(\lambda_{i}, \omega_{i}, \phi_{i}\right)$

And buy strategy

$G_{i}=\widetilde{G}_{i} \quad$ if $L_{i}^{*}\left(\omega_{i}\right) \geq \widetilde{L}_{i}\left(\lambda_{i}, \omega_{i}, \phi_{i}\right)$

Where:

$G_{i}=$ chosen institution; $G_{i}^{*}=$ internal; $\widetilde{G}_{i}=$ external;

$L_{i}^{*}=$ internal costs; $\widetilde{L}_{i}=$ market costs;

$(\lambda)$ = specificity; $(\omega)$ = complexity, $(\phi)$ = frequency

According to the approach used by Monteverde and Teece (1982), Masten (1984) and Masten et al (1991) a list of 61 components and tasks was obtained, each of which was identified as either a "make" or "buy" item by a team composed by engineers in the three analysed shipyards. The procurement teams were asked to respond a questionnaire designed to elicit relevant information about each chosen component/task such as the amount of relationship specific human capital and physical assets involved in the production process, the extent of damage to the production programme associated with having a time delay in the supply of a component/task, the complexity of a component/task and the frequency with which these components/tasks are used. It should be noted that the data refer to components and tasks that are installed or performed in a typical multipurpose medium ship, rather than in any particular ship. In this way the data should reflect the

${ }^{22}$ Several other empirical papers have used the same methodology, of which the most important are Masten (1984), Monteverde and Teece (1982) and Masten et al (1991)

${ }^{23}$ Masten's 1984 paper predates Williamson's 1985 book The Economic Institutions of Capitalism in which he identifies frequency as an important determinant of a firm's governance structure construction characteristics of commercial shipbuilding in general without being influenced by idiosyncrasies related to the construction of a particular vessel. It is important to note that most variable $^{24}$ are ranked on a 10-point scale. The exceptions to this scale are the dummy variables associated with different shipyards (SHIPYARD and SHIPYARD2), those that link components/tasks to different subsystems (HULL, ELECTRICAL, MACHINERY, OUTFITTING) and those used to indicate shipyards' size (SIZEDOLLAR, EMPLOYEES and DWT).

\subsubsection{Description of Variables}

As explained by Love and Stephen (1999) shipbuilding is essentially a construction project. Even though the ship is by its nature mobile, the bulk of the vessel involves the erection of several components and subcomponents and the execution of different tasks in a particular location. In addition, as it the case in most construction programmes, the importance of precise scheduling of different phases of work is also critical. Furthermore, because of the non-standardised nature of the components installed into the ship and the discrete nature of the production process, buffer inventories are not an economical safeguard against opportunistic behaviour. Moreover, as explained by Masten et al (1991), due to the complexity of modern ships and the uncertain demand, contracting solutions to the hold-up problem may be highly inefficient. When the level of complexity is high, it is necessary to take into account several different outcomes and writing a contract that is precise enough and at the same time flexible enough to allow changes in specifications is extremely expensive. In similar situations, firms are likely to choose vertical integration.

To assess the importance of transaction costs in the choice of governance structure in the Croatian shipbuilding industry, five TCE variables have been developed. There are three measures of specificity ${ }^{25}$ as

\footnotetext{
24 all the TCE variables

${ }^{25}$ Only three measures are used of the five explained by Williamson (1991). Site specificity is not used as it tends to be less important due to the distinctive characteristics of construction operations. On the other hand, dedicated assets are more likely to be used in naval
} 
well as complexity and frequency. The first measure (HUM) corresponding to human asset specificity was obtained by asking the respondents to specify the degree to which the component or task uses the skills and knowledge of workers who have little alternative productive use. Given that Croatian shipyards have each specialised in the production of medium complex ships, the production process should imply some human relationship specific assets ${ }^{26}$. Furthermore, the lower complexity of tasks and the relatively large number of producers of similar ships indicates that the human capital acquired may not have a high degree of specificity (Masten et al, 1991). Although the theory predicts that specific human capital is likely to raise the costs of market organisation, it may be more expensive to manage workers with similar skills. However, the variable HUM is expected to have a positive effect on the integration decision in commercial shipbuilding, even though significantly weaker than in manufacturing activities.

The second measure (AS) based on the extent to which the component/task uses equipment or facilities which have little alternative productive use was created to reflect physical asset specificity. As explained in the previous section, physical assets in construction operations tend to be less relation specific, which is also true for shipbuilding. This is because most of the equipment is designed to be mobile to allow activities on different locations around the ship while other equipment such as welding and cutting machines is often used in other industries without any modifications (Love and Stephen, 1999). Even though TCE predicts that physical asset specificity will increase the costs of organising transactions through markets, relationship-specific assets are less likely to be important in this context due to the distinctive characteristics of shipbuilding.

The third measure of specificity (TEMP) refers to the need for precise scheduling and is represented by the extent of cost involved in having a time delay in the supply of a component or task. As explained by Love

shipbuilding where series of vessels are produced for the same customer over a longer period of time (i.e. Ministry of Defence) which is not the case in commercial shipbuilding.

${ }^{26}$ e.g. Uljanik shipyard is specialised in the production of car and livestock-carriers and is one of the most important producers of these types of vessels and Stephen (1999) the key factor here is the cost of delay, which is the sum of penalties arising from the failure to deliver the product according to the contract terms and the opportunity cost of idle resources. The need for precise scheduling tends to increase the potential for hold-up and hence is associated with an increase in the costs of external procurement. Therefore, the variable TEMP is expected to positively affect shipyards' decision to vertically integrate.

Besides the variables concerning specificity, two other TCE variables are used. The extent of complexity of components to use or tasks to perform (COMPLEX) is expected to positively affect the decision to organise production internally. Complexity is usually associated with increasing the costs of internal organisation, because the firm must internalise activities outside its core competencies. However, it is argued that greater complexity increases the ink costs of contracting relative to the costs of vertical integration, which increases the probability of the latter (Williamson, 1979). Similarly, the frequency with which a component is used or a task is performed (FREQ) is also expected to increase the probability of vertical integration. This is because investments in specialised assets are easier to recover when the frequency of a transaction is higher (Williamson, 1985).

To avoid misspecification of the model, several control variables are introduced. Following Monteverde and Teece (1982b) a control variable referring to the identity of sample firms is included. As the model is a combined cross-section aggregating the data of three Croatian shipyards, two dummy variables (SHIPYARD and SHIPYARD2) are used to control for systematic differences regarding vertical integration in these firms. The omitted category is the smallest amongst the three shipyards included in the investigation: Brodosplit BSO.

The second set of control variables relate to system effects. As the ship is a system of different parts, the analysed components and tasks were grouped into four categories (hull, machinery, outfitting and electrical) and a fifth miscellaneous category. Monteverde and Teece (1982) use this set of variables to assess if different subsystems display significantly different levels of vertical integration. For this purpose, 
four dummy variables are created to represent each component's/task's membership in a subsystem. The omitted category is the miscellaneous one.

Coase (1937) argues that firms are more likely to integrate activities that are similar to their core business, as different activities tend to increase the degree of uncertainty and as a result, the costs of internal organisation. As shipbuilding involves primarily the coordination of labour intensive activities, as a measure of similarity with shipbuilding's core business, a variable (LABOUR) was included that reflects the relative capital-labour intensity of the production process (Masten et al, 1991). It is expected that the costs of internal organisation will be lower the higher the degree of labour intensity of production of a component or completion of a task.

To determine whether size of a shipyard is a significant indicator of the procurement decision, alternative measures of size (annual turnover expressed in American dollars, the number of employees in the shipyard and the total deadweight tonnage of the ships produced in the year 2004) are introduced in the last three specifications. However, because of the high collinearity between these variables and the dummy variables for shipyards, these measures cannot be included simultaneously in the model specification: either one or the other control variable can be used in the model. The following part will deal with the estimation of the make-or-buy decision in the Croatian shipbuilding industry.

\subsection{Results}

Appendix 1 presents the correlation matrix of the variables used in the regression models. All the transaction cost variables are positively correlated with the internal organisation decision, with the highest degree of correlation represented by the variable FREQ while other TCE variables have relatively low coefficients. The only exception is the variable proxy for human asset specificity, which is slightly negatively correlated with vertical integration $(-0.1131)$. The correlation between TCE variables is almost always positive, except in the case of frequency, which is negatively related to HUM and COMPLEX. On the other hand, it is necessary to note the high correlation coefficient between the last two mentioned variables (0.6372). Amongst the control variables, the labour intensity of production is strongly positively correlated with the 'make' decision. Finally, the alternative measures used as proxies for size are all positively related to integration.

The results of the probit and logit estimation are presented in Appendices 2 and 3 respectively. Even though either one or the other can be used to analyse similar datasets, the results of both are presented in this study as a mean of comparison. In addition, it is necessary to stress that since the independent variables are all ordinal in value, there is no natural interpretation of the coefficient and hence, the focus will be on the sign and significance of these coefficients. The study is presented as follows. First, specificity variables are included in the first three models. Next, the other two TCE variables that are likely to affect the decision to vertically integrate are introduced in models 4 and 5. Finally, in the last six models variables are added to control for different factors.

The first one is a simple model that tests the influence of just one variable, TEMP, on the integration decision. The coefficient on this variable is positive and highly significant at the 0.01 level. However, it is worth noting that the pseudo $\mathrm{R}^{2}$ in the probit regression is 0.0434 , which means that changes in this variable alone explain just $4.34 \%$ of the changes in the dependant variable. Yet as other variables are introduced in the model TEMP becomes insignificant and in certain specifications even negative. This leads us to conclude that the need for precise scheduling is likely to have just a weak influence on the integration decision, which is in contrast to theory predictions and previous studies (Masten et al, 1991, Love and Stephen, 1999) that found the probability that a component or task will be internalised increases when a delay in the supply of these is likely to substantially increase costs. Surprisingly, nor human asset specificity has the expected impact on the integration decision. The coefficient on the variable HUM is significant as expected but negative, indicating that the need to employ transaction-specific human assets tends to 
reduce the costs of organising transactions through markets. On the other hand, the results indicate that the more specific to a company are the assets used in the production of a component or completion of a task, the higher is the probability that the production process will be internalised. In other words, the variable AS is positive and significant at the 0.01 and 0.05 level depending on the specification of the equation.

When considering the influence of the other two TCE variables, their effect varies across different models. Complexity has an insignificant effect in models 4 and 5 but becomes positively significant after the control variable that reflects the relative capital-labour intensity of the production process (LABOUR) is introduced, while the variable FREQ is significant in the first models but becomes insignificant in model 8 when dummy variables indicating different shipyards are included.

The last three models presented in Tables 5 and 6 are models that include control variables. Model 6 adds the relative capital/labour intensity of production to control for similarity between the component or task's production process and the company's core activities. The variable LABOUR is positive and highly significant as predicted, which means that the probability of integration is higher when the production process is labour intensive, i.e. when it is more similar to shipyards' main operations. The improvement of fit is striking, from 0.1781 to 0.3545 in the probit estimation, relative to the previous model. As explained previously, the second set of control variables deals with the influence of different subsystems on the integration decision. According to the regression results, the machinery, outfitting and electrical subsystems are likely to be differently, i.e. less integrated than the omitted category which is the miscellaneous one, while the probability for the hull subsystems of displaying different levels of integration in comparison to the omitted category is not significant ${ }^{27}$. In addition, the dummy variables SHIPYARD and SHIPYARD2 are positive and significant at the $5 \%$ level, indicating that the probability for shipyards Uljanik and Trogir to

${ }^{27}$ The variables MACHINERY and OUTFITTING are significant at the 0.05 level while the variable ELECTRICAL is significant at the 0.01 level internalise another transaction is higher than for Brodosplit-BSO. In other words these two shipyards seem to be more vertically integrated than the latter one. Nevertheless, the last two sets of control variables improve substantially the explanatory power of the regression model. Finally, the empirical results indicate that size of the shipyard is likely to be a significant determinant of the 'make' decision as all the alternative measures used of size are positive and significant at the $1 \%$ level.

In sum, model 8 seems to be the most useful model for predicting the probability of vertical integration as the goodness of fit (pseudo $R^{2}$ ) is the highest both in the probit and logit estimation.

\section{Conclusions and Directions for Further Research}

This paper analyses factors influencing vertical integration in the Croatian shipbuilding industry using a Transaction Cost Economics approach. As opposed to the vast empirical literature analysing the make-or-buy decision, which is largely consistent with the transaction cost theory of the firm, the empirical results of this study give only a weak and in some way contrasting support to TCE hypothesis as only a few key variables - physical asset specificity and complexity - significantly increase the probability that a transaction will be internalised. Surprisingly, temporal specificity is not likely to influence the choice of governance structure; it seems that managers in the analysed shipyards are not aware of the possible problems and cost increases that might arise from the failure to install a component or perform a task on time. Additionally, even though according to TCE theory frequency is considered to be an important predictor of vertical integration when specialised governance structures are at stake ${ }^{28}$, in the presented setting it is not likely to increase its likelihood. However, as in commercial shipbuilding, asset specificity is less important than in other environments, frequency might not to be a crucial element when

\footnotetext{
28 "The cost of specialised governance structures will be easier to recover for large transactions of a recurring kind" (Williamson, 1985: 60)
} 
considering the choice of governance structure. However, the most striking finding is the negative and significant sign associated with the variable HUM, indicating that the presence of human relationshipspecific assets increases the probability that a component/task will be outsourced. Although the theory predicts that specific human capital is likely to raise the costs of market organisation, it seems that the analysed shipyards find it more expensive to manage workers with similar skills.

When all five TCE variables are included in the specification (Model 5), the changes in these variables explain only $17.80 \%$ of the changes in the dependent variable (governance structure) according to the probit estimation presented in Appendix 5. This means that in the case of Croatian shipyards TCE theory explains less than a fifth of the variation in the decision to 'make' or 'buy'. Yet when other control variables are introduced, in particular labour intensity of production, the fit of the model (pseudo $R^{2}$ ) increases significantly to 0.4519 , which means that variations in the independent variables explain $45.19 \%$ of the variations in the dependent variable. However, as the analysis leaves much of the variance in the patterns of vertical integration unexplained, the finding presented in this study should be seen as tentative.

There are several possible explanations why the obtained results do not give strong support to TCE theory. On one hand, these results might have been affected by several different methodological problems. First of all, it is necessary to remind that TCE variables are very difficult to measure accurately, i.e. it is very hard to find appropriate proxies for them. For this reason, this study is based on data collected using questionnaires filled by relevant persons employed in the analysed shipyards. However, as explained in the literature review of this paper, data collected in this way are based on the respondents' stated beliefs and subjective valuations. A good example is given by Masten (1994) and it is related to his previous study of the procurement decision in naval shipbuilding (Masten et al, 1991). Namely, he noted that the correlations between the two respondents for each variable used in the study were particularly low, and in some cases the correlations across variables were higher than those within the same variable. Hence, the results may be unrealistic as affected by this problem. More objective measures are necessary to increase the reliability of the results and to enhance the comparability across different industries and countries.

A second source for the problems is the absence of some control variables. Although some control variables are included in the final model, we were unable to gain important data about other control variables that may have an important and significant effect on the decision to vertically integrate, such as the engineering effort involved in developing a component/task or the extent to which a component/task is a candidate for 'load levelling' ${ }^{29}$. The non-inclusion of relevant control variables may substantially change the results of a study and lead to incorrect conclusions. It is hence important to take into account the interaction between TCE variables and other potentially relevant effects (Boerner and Macher, 2002).

Third, sample-selection problems may arise because the sample is not representative for the entire population of firms (Bigelow, 2004). As in most TCE studies, this research does not examine the relationship for an entire population of firms. This is because we did not dispose with the relevant data for all six large shipyards in Croatia. Hence, the presented results may be biased.

Finally, many authors have argued that several transaction cost studies may be methodologically flawed because they do not take into account the possible endogeneity problem (Masten, 1994; Bigelow; 2004). This problem arises from the assumption that the level of asset specificity is independent from the choice of alternative governance arrangements. They explain that the level of asset specificity is in fact endogenous, as firms' managers are usually those who make decisions regarding whether to invest in specific assets or not. However, controlling for endogeneity is

\footnotetext{
${ }^{29}$ As explained by Masten et al (1991) highly technical, engineeringintensive activities lie outside shipbuilder's main business. As a result the costs of internal organisation tend to be higher the higher the engineering effort associated with developing a component/task. On the other hand, shipyards often face the problem of underutilisation of skilled employees. To solve this problem, companies tend to internalise the production of some components that use related skills and that can be produced in periods of lower demand.
} 
extremely difficult, as it is necessary to find a suitable instrumental variable. As a result only a few researches have tackled this problem directly (e.g. Love and Stephens; 1999) finding that results change substantially when data were analysed using structural equations in comparison to reduced form equations. Hence, endogeneity bias may be another source of the weak support for TCE theory.

However, besides the possible methodological problems that might have affected the results of this study, it is necessary to concentrate also on alternative explanations. The question that arises naturally from these results is whether TCE theory is generally valid or is Croatia, and in particular its shipbuilding industry, a special case that does not fit the TCE hypothesis. It is important to remind that the Croatian state was part of the former Yugoslavia until 1991, when it proclaimed independence. Furthermore, as is well known, the former Yugoslavia was a socialist country, a centrally planned economy where amongst the most important objectives were full employment and social rights. As a consequence, the production process was organised almost completely inside shipyards, in accordance with the socialist principles of production. Croatian shipyards began the restructuring process that implied decreasing drastically the number of employees and increasing the level of outsourcing in 1995. Nevertheless, this process is not yet complete and organisational structures are still changing in Croatian shipyards. On the other hand, the analysed shipyards have not yet been privatised and decisions are often driven by political interests and lobbies rather than cost minimisation reasoning. Hence, we believe that the weak support of TCE theory has been primarily the consequence of country factors such as those explained above and of its historical background. This does not mean that TCE is flawed. As demonstrated by the vast amount of empirical work in accordance with theory predictions, it seems that TCE is at least valid for highly developed countries such as US and the UK. However, to test its overall validity, further research based on other developed as well as developing countries is necessary. This study is, to our knowledge, the first empirical work that analyses the make-or-buy decision in a former socialist Eastern European country using a TCE approach. Nevertheless, significantly more effort is necessary. As explained by Williamson (1992: 349), "Transaction cost economics needs to be refined and extended. It needs to be qualified and focused. It needs to be tested empirically". However, economotribologists ${ }^{30}$ must be aware of the possible methodological problems that might undermine the correctness of their results, such as difficulties related to variables measurement, missing control variables, simultaneity and selection biases. Hence, they must also concentrate on solving these problems to increase the reliability and comparability of the obtained results. [

\section{References}

Arrow, Kenneth. 1969. "The organisation of economic activity: issues pertinent to the choice of market versus non-market allocation." Washington DC, US Joint Economic Committee: $91^{\text {st }}$ Congress.

Bartlett, Will, Bateman, Milford, Vehovec, Maja. 2002. Small Enterprise Development in South-East Europe: Policiesfor Sustainable Growth, Boston: Kluwer.

Bateman, Milford, Kastelan-Mrak, Marija, Vehovec, Maja. 1998. „Industrial Restructuring and the Promotion of Small Enterprise Clusters: the Case of Shipbuilding and Repair Industry in the Republic of Croatia" Journal of Applied Management Studies, 7 (1).

Besanko, David, Dranove, David and Shanley, Mark. 1996. Economics of Strategy. New York: Wiley.

Bigelow, Lyda S., 2004. "Make-or-Buy Revisited: A Longitudinal, Population-wide Test of Transaction Cost Alignement" Submitted to Journal of Economic Behaviour and Organization.

Bitzer, Jurgen, vn Hirschhausen, Christian. 1997. "The Shipbuilding Industry in East and West: Industry Dynamics, Science and Technology Policies and Emerging Patterns of Co-operation" Deutsches Institut fur Wirtschaftsforschung, Discussion Paper No. 151, Berlin.

Boerner, Cristopher, Macher, Jeffrey. 2002 "Transaction Cost Economics: An Assessment of Empirical Research in the Social Sciences" Journal of Law, Economics and Organization.

Caves, Richard and Bradburd, Ralph. 1988. "The empirical determinants and vertical integration." Journal of Economic Behaviour and Organisation, 9 (2), pp. 265-279.

Coase, Ronald H. 1937, "The Nature of the Firm." Economica, pp. 386-405.

\footnotetext{
${ }^{30}$ Transaction cost economists (neologism from ECONO(MICS) + TRIBOLOGY, the science of the mechanisms of frictions) as explained by Masten (2001)
} 
Coase, Ronald H. 2000 "The Acquisition of Fisher Body by General Motors." Journal of Law and Economics, 43, pp.15-31.

Croatia Outlook 1997. 3(1) Zagreb.

Croatian Chamber of Economy. 2003. "Shipbuilding Industry" Zagreb.

Croatian Chamber of Economy. 2005. "Shipbuilding Industry" Zagreb.

Dahlman, Carl. 1979. "The problem of externality." Journal of Law and Economics. 22 (1), pp. 141-162.

Douma, Sytse and Schreuder, Hein 1998. Economic Approaches to organisations. Hemel Hempstead: Prentice Hall.

Eccles, R. G., 1981. "The Quasifirm in the Construction Industry", Journal of Economic Behavior and Organization, 2, pp. 335-57.

Goffman, I., 1969. Strategic Interaction. Philadelphia: University of Pennsylvania Press.

González,-Diaz, Manuel, Benito Arruñada, and Alberto Fernández. 2000. "Causes of Subcontracting: Evidence from Panel Data on Construction Firms," Journal of Economic Behavior and Organization 42, pp. 167-87.

Gujarati, Damodar, 1992. Essentials of Econometrics. New York: McGraw-Hill.

Hagedoorn, J., 1993. "Understanding the Rationale of Strategic Technology Partnering: Interorganizational Modes of Cooperation and Sectoral Differences", Strategic Management Journal, 14, pp. 371385

Hendrikse, George. 2003. Economics and management of organisation. Maidenhead: McGraw-Hill.

Hodgson, Geoffrey 1988. Economics and institutions: a manifesto for a modern institutional economics. Oxford: Blackwell Publishers.

Joskow, Paul 1985. "Vertical integration and long term contracts: the case of coal-burning electric generating plants." Journal of Law, Economics and Organization, 1, pp. 33-80.

Joskow, Paul 2003. "Vertical Integration", Forthcoming, Handbook of New Institutional Economics, Kluwer.

Kanerva, Markku, Lietepohja, Matti, Hakulinen, Petri. 2002.

"Shipbuilding Process - Challenges and Opportunities", Deltamarin.

Klein, Benjamin, Crawford, Robert, Alchian, Armen. 1978. "Vertical integration, appropriable rents and the competitive contracting process." Journal of Law and Economics, 21, pp. 297-326.

Klein, Benjamin. 1988. "Vertical integration as organisational ownership: the Fisher Body-GM relationship revisited." Journal of Law and Economics, 4 (1), pp. 3-17.

Klein, Benjamin. 2000 "Fisher-General Motors and The Nature of The Firm" Journal of Law and Economics, vol. XLIII, pp. 105-141.

Klein, Peter G. 2004. "The make-or-buy decision: lessons from empirical studies." University of Missouri at Columbia: Contracting and Organisations Research Institute. Working Paper Number 2004 07, April.

Levy, David. 1985. "The transaction cost approach to vertical integration: an empirical examination." Review of Economics and Statistics, 67, pp. 438-445.

Love, James H., Stephen, Frank H. 1999 "Contractual Failure, Market Failure and the make-or-buy Decision" Washington DC, Society for New Institutional Economics: Third Annual Conference International.

Knight, Frank, 1921. Risk, uncertainty and profit. New York: Harper \& Row. Reprinted 1933. London: LSE.

MacDonald, J.M., 1985 "Market Exchange or Vertical Integration: An Empirical Analysis" Review of Economic and Statistics, 67, pp. 327-331.

Masten, Scott E., 1984. "The organisation of production: evidence from the aerospace industry." Journal of Law and Economics, 27, pp 403-417.

Masten, Scott E., Meehan, James and Snyder, Edward 1989. "Vertical Integration in the U.S. Auto Industry" Journal of Economic Behavior and Organization, 12 , pp. 265-273.

Masten, Scott E., Meehan, James and Snyder, Edward 1991. "The costs of organisation" Journal of Law, Economics and Organisation, 7 (1), pp. 1-26.

Masten, Scott E., 1994. "Empirical Research in Transaction Cost Economics: Challenges, Progress, Directions", Presented at the conference Transaction Cost Economics and Beyond, Rotterdam.

Masten, Scott E., 2000. "Reaffirming Relationship-Specific Investments" Michigan Law Review, August, pp. 2668-77.

Milgrom, Paul, and Roberts, John, 1992. Economic organisations, Englewood Cliffs, NJ: Harvester Wheatsheaf.

Ministry of Economic Affairs 1997. Published information obtained from the Directorate of Industry and Shipbuilding, Ministry of Economic Affairs, Zagreb.

Monteverde, Kirk, and Teece, David, 1982 a. "Appropriable rents and quasi-vertical integration." Journal of Law and Economics, pp. 321-283.

Monteverde, Kirk, and Teece, David, 1982 b. "Supplier switching costs and vertical integration in the automobile industry." Bell Journal of Economics, pp. 206-13.

Palay. Thomas, 1984. "Comparative institutional economics: the governance of rail freight contracting." The Journal of Legal Studies, 13 , pp. $265-287$

Rao, Pinninti K. 2003. The Economics of Transaction Costs. New York: Palgrave Macmillan.

Rindfleisch, Aric, Heide, Jan B. 1997 "Transaction Cost Economics: Past, Present, and Future Applications" Journal of Marketing, 61, pp. 30-54.

Shelanski, Harold, and Klein, Peter, 1995. "Empirical research in transaction cost economics: a review and assessment." Journal of Law, Economics and Organisation. 11(2), pp. 335-361. 
Simon, Herbert, 1957. Models of Man. London: Macmillan.

Walker, Gordon and Weber, David 1984. "A transaction cost approach to make-or-buy decisions." Administrative Science Quarterly, 29, pp. 373-391.

Williamson, Oliver E., 1975. Market and hierarchies: analysis and antitrust implications. New York: Free Press.

Williamson, Oliver E., 1976. "Franchise bidding for natural monopolies." Bell Journal of Economics, Spring (1), pp. 73-104.

Williamson, Oliver E., 1979. "Transaction-Cost Economics: The Governance of Contractual Relations", Journal of Law and Economics, 22, pp. 232-262.

Williamson, Oliver E., 1985. The Economic Institutions of Capitalism. New York: Free Press.

Williamson, Oliver E. 1986. Economic Organisation. Brighton: Wheatsheaf Books.

Williamson Oliver E., 1991. "Comparative economic organisation: the analysis of discrete structural alternatives." Administrative Science Quarterly, 36, pp. 269-296.

Williamson Oliver E., 1992. "Markets, Hierarchies and the Modern Corporation" Journal of Economic Behavior and Organization, 17, pp. 335-52

http://www.hb.hr - This website address is correct at time of writing (22 $2^{\text {nd }}$ July 2007)

\section{Appendices}

\section{Appendix 1: Correlation matrix}

\begin{tabular}{|c|c|c|c|c|c|c|c|c|c|c|c|c|c|c|c|}
\hline & make & temp & hum & as & freq & complex labour & hull & machinery & utfitting $e$ & electrical & all & shipyard & hipyard2 s & zedollar employ. & dwt \\
\hline MAKE & 1.0000 & & & & & & & & & & & & & & \\
\hline TEMP & 0.2391 & 1.0000 & & & & & & & & & & & & & \\
\hline HUM & -0.1131 & 0.4089 & 1.0000 & & & & & & & & & & & & \\
\hline AS & 0.2094 & 0.3124 & 0.3731 & 1.0000 & & & & & & & & & & & \\
\hline COMPLEX & 0.0226 & 0.2628 & 0.6372 & 0.4993 & 1.0000 & & & & & & & & & & \\
\hline FREQ & 0.3889 & 0.3404 & -0.2591 & 0.0058 & -0.2177 & 1.0000 & & & & & & & & & \\
\hline LABOUR & 0.4456 & 0.1783 & 0.0702 & 0.0184 & -0.0470 & $0.1384 \quad 1.0000$ & & & & & & & & & \\
\hline HULL & 0.2089 & 0.1728 & -0.1224 & 0.1988 & -0.1729 & $0.2681-0.0358$ & 1.0000 & & & & & & & & \\
\hline MACHINERY & -0.3305 & -0.1855 & 0.2205 & -0.0324 & 0.2318 & $-0.5918-0.2466$ & -0.3414 & 1.0000 & & & & & & & \\
\hline OUTFITTING & -0.0127 & -0.2206 & -0.1534 & -0.1081 & -0.1627 & 0.02220 .1556 & -0.2937 & -0.3782 & 1.0000 & & & & & & \\
\hline ELECTRICAL & -0.1004 & 0.0096 & -0.0058 & -0.0778 & 0.0708 & $-0.0096-0.0396$ & -0.1676 & -0.2158 & -0.1857 & 1.0000 & & & & & \\
\hline ALL & 0.2915 & 0.3057 & 0.0456 & 0.0099 & 0.0365 & $0.4468 \quad 0.2075$ & -0.2110 & -0.2716 & -0.2337 & -0.1334 & 1.0000 & & & & \\
\hline SHIPYARD & 0.1402 & -0.0722 & -0.2540 & -0.1729 & -0.1842 & $0.1483-0.0907$ & 0.0677 & -0.0170 & -0.0282 & -0.0357 & 0.0083 & 1.0000 & & & \\
\hline SHIPYARD2 & -0.0120 & -0.1834 & -0.1586 & 0.0234 & -0.0898 & $0.1224-0.1935$ & 0.0677 & -0.0170 & -0.0282 & -0.0357 & 0.0083 & -0.5755 & 0.0677 & & \\
\hline SIZEDOLLAR & 0.1626 & -0.2223 & -0.4264 & -0.1942 & -0.2908 & $0.2707-0.2523$ & 0.1322 & -0.0332 & -0.0551 & -0.0697 & 0.0162 & 0.8018 & 0.0274 & 1.0000 & \\
\hline EMPLOYEES & 0.1634 & -0.2086 & -0.4144 & -0.1958 & -0.2840 & $0.2615-0.2379$ & 0.1271 & -0.0319 & -0.0530 & -0.0670 & 0.0155 & 0.8435 & -0.0462 & $0.9973 \quad 1.0000$ & \\
\hline DWT & 0.1611 & -0.1667 & -0.3715 & -0.1949 & -0.2583 & $0.2301-0.1932$ & 0.1103 & -0.0277 & -0.0459 & -0.0581 & 0.0135 & 0.9324 & -0.2410 & $0.9636 \quad 0.9806$ & 1.0000 \\
\hline
\end{tabular}


Appendix 2: Probit make-or-buy estimation

$\begin{array}{lllllll}\text { Model } 1 & \text { Model } 2 & \text { Model } 3 & \text { Model } 4 & \text { Model } 5 & \text { Model } 6 & \text { Model } 7\end{array}$

Constant

$-0.860$

$-0.561 \quad-0.881$

$-0.947$

$-1.608$

$-3.905$

$-2.969$

$(3.95)^{* * *}$

$(2.37)^{* *}$

$(3.27)^{* * *}$

$(3.20)^{* * *}$

$(4.32)^{* * *}$

$(5.88)^{* * *}$

$(3.26)^{* * *}$

TEMP

$$
\begin{aligned}
& 0.108 \\
& (3.12)^{* * *}
\end{aligned}
$$

0.156

0.137

0.139

0.062

0.002

$-0.032$

HUM

$(3.77)^{* * *}$

$(3.15)^{* * *}$

$(3.15)^{* * *} \quad(1.27)$

(0.04)

(0.57)

$-0.123$

$-0.169$

$-0.188$

$-0.129$

$-0.187$

$-0.212$

$(2.79)^{* * *}$

$(3.42)^{* * *}$

$(3.16)^{* * *}$

$(2.12)^{* *}$

$(2.45)^{* *}$

$(2.65)^{* * *}$

AS

0.156

0.144

0.142

0.204

0.187

$(3.13)^{* * *}$

$(2.74)^{* * *}$

$(2.80)^{* * *}$

$(3.12)^{* * *}$

$(2.62)^{* * *}$

COMPLEX

0.044

0.073

0.174

0.227

$(0.65)$

(1.03)

$(2.07)^{* *}$

$(2.51)^{* *}$

FREQ

0.130

0.163

0.121

$(3.53)^{* * *}$

$(3.48)^{* * * *}$

$(2.04)^{* *}$

LABOUR

0.402

0.428

$(5.60)^{* * *}$

$(5.10)^{* * *}$

HULL $-0.335$

MACHINERY

$-0.869$

$(1.82)^{*}$

OUTFITTING

$-0.941$

$(2.30)^{* *}$

ELECTRICAL

$-1.383$

$(3.14)^{* * *}$

SHIPYARD

SHIPYARD2

SIZEDOLLAR

EMPLOYEES

DWT

Observations $\quad 167 \quad 167$

$167 \quad 167$

167

167

167

Robust t-statistics in parentheses

* significant at 10\%; ** significant at 5\%; ${ }^{* *}$ significant at $1 \%$

$\begin{array}{lllll}\text { Pseudo }^{2} & 0.0434 & 0.0845 & 0.1240 & 0.1259\end{array}$

$0.1780 \quad 0.3530$

0.3838 


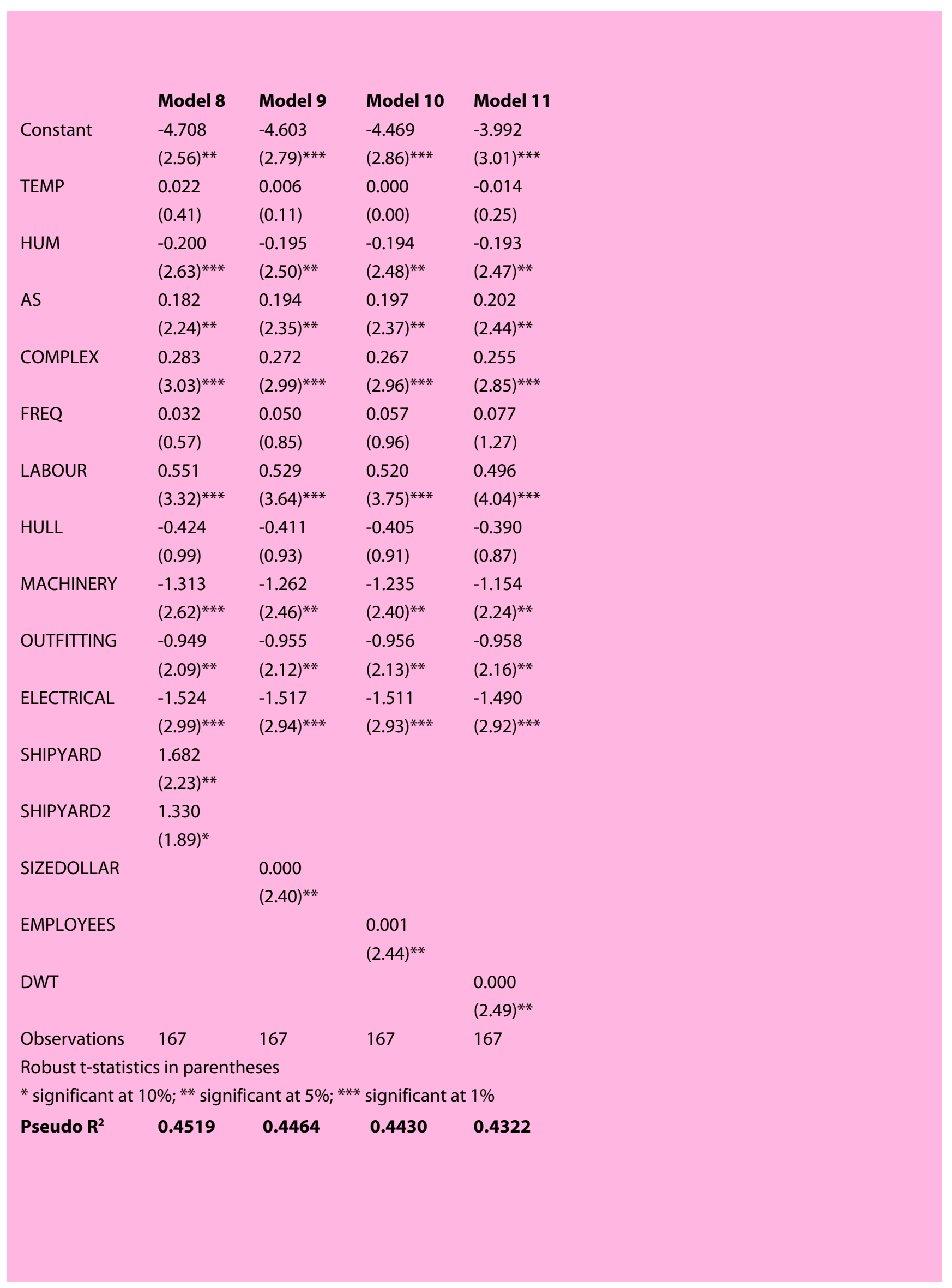


Appendix 3: Logistic make-or-buy estimation

\begin{tabular}{|c|c|c|c|c|c|c|c|}
\hline & Model 1 & Model 2 & Model 3 & Model 4 & Model 5 & Model 6 & Model 7 \\
\hline \multirow[t]{2}{*}{ Constant } & -1.383 & -0.897 & -1.436 & -1.566 & -2.672 & -6.818 & -5.428 \\
\hline & $(3.87)^{* * *}$ & $(2.33)^{* *}$ & $(3.18)^{* * *}$ & $(3.11)^{* * *}$ & $(4.08)^{* * *}$ & $(5.53)^{* * *}$ & $(3.35)^{* * *}$ \\
\hline \multirow[t]{2}{*}{ Constant } & 0.173 & 0.259 & 0.235 & 0.242 & 0.112 & 0.015 & -0.045 \\
\hline & $(3.08)^{* * *}$ & $(3.60)^{* * *}$ & $(3.05)^{* * *}$ & $(3.01)^{* * *}$ & $(1.32)$ & $(0.16)$ & $(0.43)$ \\
\hline \multirow[t]{2}{*}{ TEMP } & & -0.206 & -0.288 & -0.326 & -0.221 & -0.322 & -0.376 \\
\hline & & $(2.68)^{* * *}$ & $(3.17)^{* * *}$ & $(2.94)^{* * *}$ & $(2.08)^{* *}$ & $(2.07)^{* *}$ & $(2.19)^{* *}$ \\
\hline \multirow[t]{2}{*}{ HUM } & & & 0.257 & 0.235 & 0.230 & 0.354 & 0.334 \\
\hline & & & $(3.04)^{* * *}$ & $(2.71)^{* * *}$ & $(2.77)^{* * *}$ & $(2.86)^{* * *}$ & $(2.58)^{* *}$ \\
\hline \multirow[t]{2}{*}{ AS } & & & & 0.082 & 0.127 & 0.300 & 0.399 \\
\hline & & & & $(0.72)$ & (1.04) & $(1.98)^{* *}$ & $(2.27)^{* *}$ \\
\hline \multirow[t]{2}{*}{ COMPLEX } & & & & & 0.215 & 0.281 & 0.217 \\
\hline & & & & & $(3.45)^{* * *}$ & $(3.22)^{* * *}$ & $(2.04)^{* *}$ \\
\hline \multirow[t]{2}{*}{ FREQ } & & & & & & 0.698 & 0.755 \\
\hline & & & & & & $(5.39)^{* * *}$ & $(4.94)^{* * *}$ \\
\hline \multirow[t]{2}{*}{ LABOUR } & & & & & & & -0.482 \\
\hline & & & & & & & $(0.66)$ \\
\hline \multirow[t]{2}{*}{ HULL } & & & & & & & -1.353 \\
\hline & & & & & & & $(1.69)^{*}$ \\
\hline \multirow[t]{2}{*}{ MACHINERY } & & & & & & & -1.560 \\
\hline & & & & & & & $(2.23)^{* *}$ \\
\hline \multirow[t]{2}{*}{ OUTFITTING } & & & & & & & -2.256 \\
\hline & & & & & & & $(3.00)^{* * *}$ \\
\hline
\end{tabular}

ELECTRICAL

SHIPYARD

SHIPYARD2

SIZEDOLLAR

EMPLOYEES

DWT

$\begin{array}{llllllll}\text { Observations } & 167 & 167 & 167 & 167 & 167 & 167 & 167\end{array}$

Robust t-statistics in parentheses

${ }^{*}$ significant at $10 \% ;{ }^{* *}$ significant at $5 \% ;{ }^{* * *}$ significant at $1 \%$
Pseudo $\mathbf{R}^{2}$
0.0430
0.0848
0.1247
0.1270
0.1781
0.3545
0.3851 


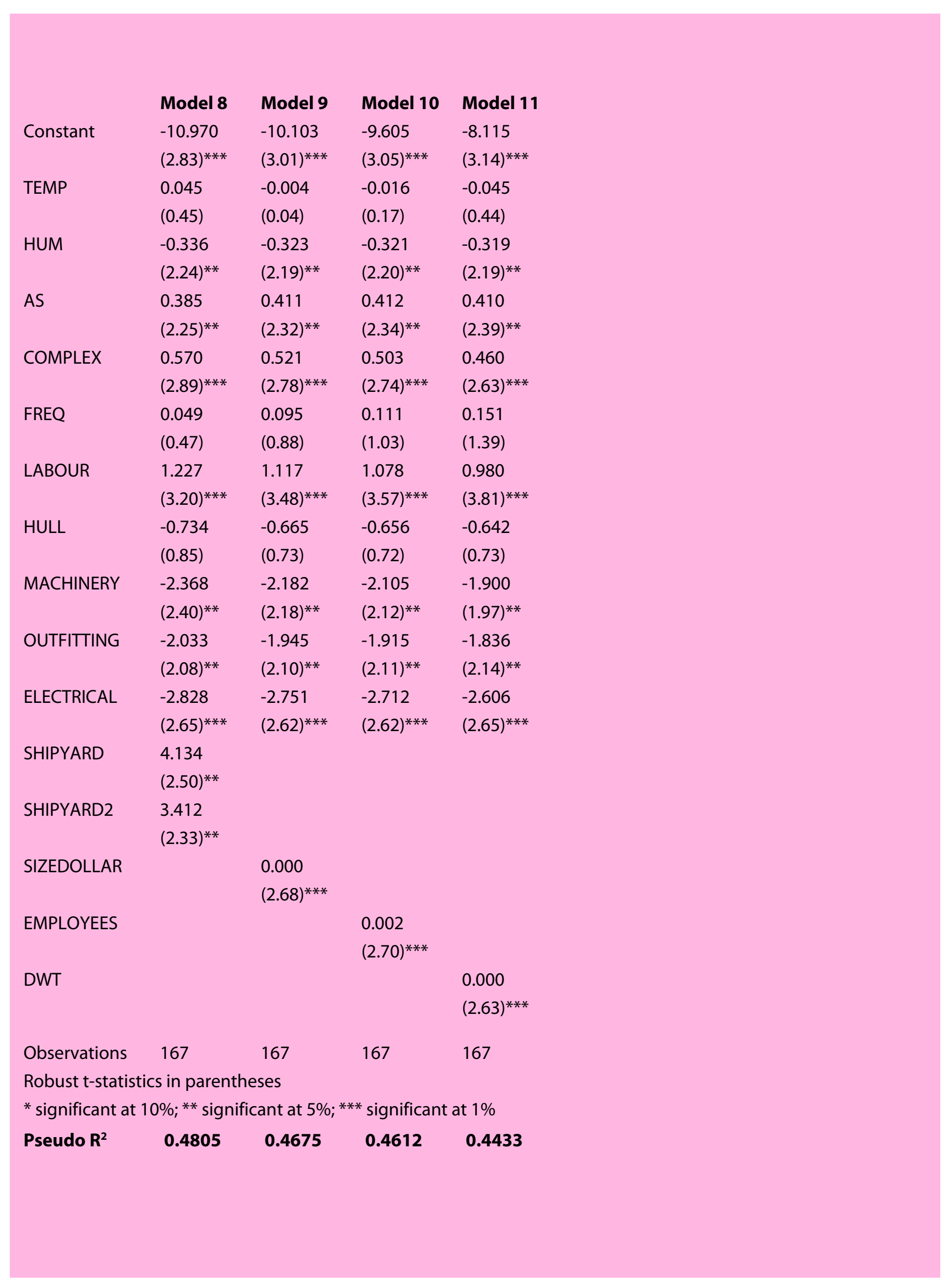

